\title{
THE CITY MANAGER'S KNOWLEDGE \\ OF GRANTS-IN-AID
}

\section{Some Personal and Environmental Influences}

\author{
F. TED HEBERT and RICHARD D. BINGHAM \\ University of Oklahoma
}

\begin{abstract}
Evidence from public officials at all levels of government indicates that the profusion and excessive categorization of grants has had adverse consequences. State and local officials complain of an "information gap"-confusion and uncertainty as to what granis are available, who administers them, what the varying requirements are, how closely related grants differ, how to go about making proper application [Advisory Commission on Intergovernmental Relations, 1967: 12$]$.
\end{abstract}

While it is generally recognized that this "information gap" does exist, there has been little done in an effort to measure and evaluate local officials' knowledge of grants-in-aid. This research note summarizes the major results of such an attempt within the four state area of Arkansas, Kansas, Missouri, and Oklahoma. ${ }^{1}$ The survey covered the 148 cities with a population of less than 100,000 with a council-manager government. (The few city manager cities over 100,000 population were cut off to avoid distortion of the survey results.)

\section{METHODOLOGY}

Fifty-seven grants-in-aid programs were selected from the 1,013 listed titles in the OEO Catalog of Federal Domestic A ssistance because these 57 
applied equally to all cities, regardless of size, geographic features, or possible variations in municipal structure (e.g., integrated versus independent school districts).

Each city manager was asked, by mailed questionnaire, to evaluate his knowledge of each of the grants-in-aid by selecting the one category that best described his knowledge of the program. (The questionnaire made no attempt to test the manager's actual knowledge of the programs, only his reported knowledge.) The categories were:

(1) I have used, or am now using, this program.

(2) I know the details of this program concerning its objectives, uses and restrictions, application process, and matching requirements (if any).

(3) I am aware of the prominent features of this program.

(4) I have heard of this program, but I have a limited knowledge of its features.

(5) I am not familiar with this program.

Points were assigned to the managers' replies: Four points for the "have used, or am now using" response and to the "know the details" response; three points for the "prominent features" response, two for the "heard of the program" response; and one for the "not familiar" response.

\section{FINDINGS}

Average scores for the programs ranged from 1.44 to 3.67 , with a mean of 2.39 and a standard deviation of .57. Different explanations of this variation were then tested statistically. For example, computation of the correlation coefficient between the program scores and the 1970 estimated congressional obligations suggested that, although statistically significant, the coefficient was too low to conclude that program scores can be explained totally by the dollar obligations.

Examining the mean scores by administering agency showed that HUD programs are better known by our city managers than are the programs of HEW and OEO. However, the data do not permit a determination whether this results from particular efforts on the part of HUD officials or whether it results from the particular types of programs sponsored by that agency. 
Knowledge scores were also averaged by manager, yielding a reported knowledge score for each manager. These scores range from 1.25 to 3.81 , with a mean of 2.40 and a standard deviation of .54 . Three independent variables seem useful in explaining this range: city size, education level of the manager, and the use of a grantsman. No significant relationship was found between a manager's knowledge and his prior experience.

City size yielded the strongest relationship, bearing out the expectation that managers of larger cities would exhibit higher knowledge. Among managers in cities of 10,000 and over, $47 \%$ are in the higher one-third on knowledge, and only $10 \%$ in the lower. In cities less than 5,000 , only $7 \%$ are in the high category and $86 \%$ in the low. The relationship between manager's education and city size was also tested, using each as a control variable: the positive relationship between city size and knowledge remained significant in all education categories, whereas the impact of education is confined to the larger cities (10,000 and over).

The employment of a grantsman was also found to relate significantly to knowledge. The few managers in the study employing grantsmen (28\%) clearly report higher knowledge levels. Introducing city size as a control showed the impact of a grantsman was most pronounced in the small cities, and the relationship was slightly negative in the large cities. This may reflect a tendency for those managers of larger cities who do not employ grantsmen to be, themselves, particularly knowledgeable about federal programs, or, perhaps, managers employing grantsmen rely heavily on them and hence do not acquire a high personal knowledge.

Comparable testing and analysis of the manager's level of knowledge was also undertaken for the set of programs administered by HUD, HEW, and OEO, respectively. The results differed somewhat from those noted above, as well as among these agencies. For example, the manager's education had a larger positive influence on knowledge of OEO programs in small cities, while the use of a grantsman played little role in the development of knowledge of OEO programs. City size, however, remained as the most pervasive explanatory variable.

\section{NOTE}

1. A complete report on this study is available by writing the authors, in care of the Department of Political Science, University of Oklahoma, Norman, Oklahoma 73069. 


\section{REFERENCES}

Advisory Commission on Intergovernmental Relations (1967) Fiscal Balance in the American Federal System. Volume I. Washington, D.C.: Government Printing Office.

International City Management $\Lambda$ ssociation (1970) Municipal Management Directory 1970. Washington, D.C.

MUSHKIN, S. J. and J. F. COTTON (1969) Sharing Federal Funds for State and Local Needs: Grants-In-Aid and PPB Systems. New York: Frederick A. Praeger.

Office of Economic Opportunity (1970) Catalog of Federal Domestic Assistance. Washington, D.C.: Government Printing Office.

REUSS, H. S. (1970) Revenue Sharing: Crutch or Catalyst. New York: Praeger.

SEGAL, M. and A. L. FRITSCHLER (1.970) "Emerging patterns of intergovernmental relations," pp. 13-38 in The Municipal Year Book 1970. Washington, D.C.: International City Management Association.

WRIGHT, D. S. (1968) Federal Grants-In-Aid: Perspectives and Alternatives. Washington, D.C.: American Enterprise Institute for Public Policy Research.

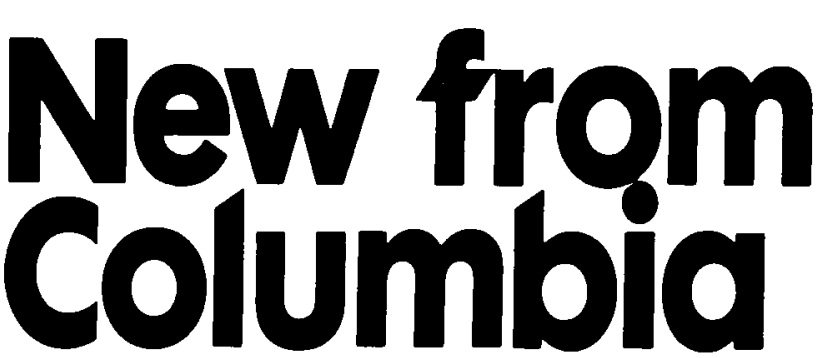

THE NECESSARY MAJORITY:

Middle America And The Urban Crisis

\section{ROBERT C. WOOD}

Dr. Wood reviews analytically the recognition in the 1960's of the problems of American cities and the development of legislation and programs to deal with them, and goes on to give his own knowledgeable prescriptions for the difficulties of urban life in America. Continuation of beginnings made in the 1960's is urged as are efforts at institutional change and economic development and renewal.

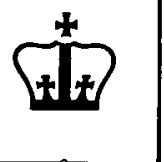

\section{COLUMBIA UNIVERSITY PRESS}

Address for orders: 136 South Broadway, Irvington, New York 10533

Please mention URBAN AFFAIRS QUARTERLY when writing advertisers. 